\title{
Under-nutrition and associated factors among children infected with human immunodeficiency virus in sub-Saharan Africa: a systematic review and meta- analysis
}

Jemberu Nigussie ${ }^{1 *} \mathbb{D}$, Bekahegn Girma', Alemayehu Molla², Moges Mareg ${ }^{3}$ and Esmelealem Mihretu ${ }^{4}$

\begin{abstract}
Background: In the developing world, such as the sub-Saharan African region, HIV/AIDS has worsened the impact of under-nutrition in children. HIV infected children are highly vulnerable to under-nutrition. Therefore, the objective of this systematic review and meta-analysis was to estimate the pooled prevalence of under-nutrition, and the pooled effect sizes of associated factors among HIV-infected children in sub-Saharan Africa.

Methods: The primary studies for this review were retrieved from PubMed/ MEDLINE online, Science Direct, Hinari, web of science, CINHAL, EMBASE, WHO databases, Google, and Google Scholar databases. The articles selected for this meta-analysis were published between 2010 and 2020. The last search date was 18 October 2021. The data was extracted in Microsoft Excel format and exported to STATA Version 14.0. A random effect meta-analysis model was used. Heterogeneity was evaluated by the $\mathrm{I}^{2}$ test. The Egger weighted regression test was used to assess publication bias.

Results: We retrieved 847 records from these databases. Of which records, 813 were excluded due to different reasons and 34 studies were included in the final analysis. The pooled prevalence of stunting, underweight and wasting in HIV infected children was $46.7 \%$ (95\% Cl; 40.36-53.07, $\left.\mathrm{I}^{2}=98.7 \%, p<0.01\right), 35.9 \%$ (95\% Cl; 30.79-41.02, $\left.\mathrm{I}^{2}=97.4 \% p<0.01\right)$, and 23.0\% (95\% Cl; 18.67-27.42, $\left.I^{2}=96.9 \%, p<0.01\right)$ respectively. The advanced WHO HIV/AIDS clinical staging (III\&IV) [OR= 6.74 (95\%: 1.747, 26.021), $\left.I^{2}=94.7 \%\right]$ and household food insecurity were associated with stunting $[O R=5.92(95 \% \mathrm{Cl} 3.9$, 8.87), $\mathrm{I}^{2}=55.7 \%$ ]. Low family economic status [OR $=4.737(95 \% \mathrm{Cl}: 2.605,8.614), \mathrm{I}^{2}=31.2 \%$ ] and increased feeding frequency $\left[\mathrm{OR}=0.323(95 \% \mathrm{Cl}: 0.172,0.605), \mathrm{I}^{2}=69.8 \%\right]$ were significantly associated with under-weight. Anemia $[\mathrm{OR}=$ 2.860 (95\% Cl: 1.636, 5.000), $\left.\mathrm{I}^{2}=74.8 \%\right]$ and diarrhea in the previous month [OR $\left.=4.117(95 \% \mathrm{Cl}: 2.876,5.894), \mathrm{I}^{2}=0.0 \%\right]$ were also associated with wasting among HIV infected children in sub-Saharan Africa.
\end{abstract}

\footnotetext{
* Correspondence: jemberu2123@gmail.com

'Department of Nursing College of Health Sciences and Medicine, Dilla University, Dilla, Ethiopia

Full list of author information is available at the end of the article
}

(C) The Author(s). 2022 Open Access This article is licensed under a Creative Commons Attribution 4.0 International License, which permits use, sharing, adaptation, distribution and reproduction in any medium or format, as long as you give appropriate credit to the original author(s) and the source, provide a link to the Creative Commons licence, and indicate if changes were made. The images or other third party material in this article are included in the article's Creative Commons licence, unless indicated otherwise in a credit line to the material. If material is not included in the article's Creative Commons licence and your intended use is not permitted by statutory regulation or exceeds the permitted use, you will need to obtain permission directly from the copyright holder. To view a copy of this licence, visit http://creativecommons.org/licenses/by/4.0/ The Creative Commons Public Domain Dedication waiver (http://creativecommons.org/publicdomain/zero/1.0/) applies to the data made available in this article, unless otherwise stated in a credit line to the data. 
Conclusions: The pooled prevalence of under-nutrition among HIV infected children was high. Nutritional assessment and interventions need great attention as a part of HIV care for HIV positive children. The implementation of policies and strategies established by national and international stakeholders in ART care centres should take a maximum emphasis on reducing under-nutrition among HIV infected children.

Keywords: Under-nutrition, Malnutrition, Children, Sub-Saharan Africa, Human immunodeficiency virus, HIV positive children

\section{Background}

Worldwide, both under-nutrition and human immunodeficiency virus (HIV) are highly prevalent, particularly in the sub-Saharan Africa region [1]. In the world, nearly 2.84 million children under 19 years in 2019 were living with HIV, and more than $90 \%$ were in the sub-Saharan Africa region [2]. In 2018, approximately 49 and 149 million under-five children were stunted and wasted, respectively, and more than $90 \%$ lived in low and middleincome countries [3]. The magnitude of stunting and wasting in Sub-Saharan Africa varies in the region by as much as 32 and 10\%, respectively [4]. HIV/AIDS, poverty, and food insecurity were the main causes of these high under-nutrition problems [5]. Studies have shown that stunting, under-weight, and wasting were more prevalent among HIV infected children than uninfected children [6-8].

Under-nutrition is responsible for about $11 \%$ of the global disease burden [9], more than $35 \%$ of child deaths [10], and deformities such as cognitive impairment, chronic diseases, and growth failure [10]. In a resourcelimited setting, more than one-third of under five children mortality was due to under-nutrition every year [11]. In HIV infected children the risk of death due to under-nutrition is three-times higher than non-HIV infected children [12]. The magnitude of severe undernutrition, hospitalization and death rates reaches as high as $20-50 \%$ among HIV infected or exposed children in sub-Saharan Africa [13, 14].

HIV/AIDS, under-nutrition, and lack of essential micronutrients affect the immune system, leading to a nutritionally acquired immune dysfunction syndrome that increases susceptibility to infection which complicates the case managements $[13,15,16]$. HIV infection increases the risk of under-nutrition due to the high activity of pro-inflammatory cytokines that causes growth impairment [17]. HIV-related opportunistic infections, such as persistent diarrhoea, oral, and oesophageal candidiasis, have negative impact on the nutritional status of the patient [18]. Furthermore, initially ART in children can also cause metabolic disorders and adverse effects on nutritional status that causes complications such as nausea and vomiting or reduced bone mineral density, especially in the first months of treatment [19].

The clinical context and interventions for most causes of childhood mortality worldwide have been addressed over the last decade $[18,20]$, but the management of under-nutrition in children, particularly those infected with HIV, remains poorly addressed [21]. Studies reported differing magnitudes of low nutritional status of HIV infected children and identified study settingspecific factors. The prevalence of stunting, underweight and wasting in sub-Saharan Africa ranged from 13.4 to $77 \%, 6.8$ to $56.3 \%$ and 2.5 to $52 \%$ respectively [22-27]. This showed pronounced discrepancies among reports of under nutrition across different geographical settings and different time periods. Furthermore, there are no regionally represented pooled data of under nutrition in in sub-Saharan Africa.

Subsequently, reliable and summarized information is essential to refine governments' policies, strategies, and interventions. Therefore, the aim of this systematic review and meta-analysis was to estimate the pooled prevalence of under-nutrition, and the pooled effect sizes of factors associated with under-nutrition among HIV infected children in sub-Saharan Africa. Therefore, this review can be of vital importance in showing summarized evidence and suggesting possible applicable strategies for planning, decision making, and resource allocation in the health care system of the sub-Saharan Africa region.

\section{Review question}

What is the pooled prevalence of under-weight, wasting and stunting among HIV infected children in the subSaharan Africa from 2010 to 2021 ?

What is the pooled effect size of associated factors for under-nutrition among HIV infected children in the sub-Saharan Africa from 2010 to 2021?

\section{Methods \\ Study identification}

The Preferred Reporting Items for Systematic Reviews and Meta-Analyses (PRISMA) guideline was used to write this systematic review and meta-analysis [28]. The published and unpublished literature (Grey literature) describing the prevalence and associated factors of under-nutrition (stunting, wasting, and under-weight) among HIV infected children were reviewed.

\section{Eligibility criteria}

Observational studies including cross-sectional, comparative cross-sectional, case-control, and cohort studies 
reporting the prevalence of under-nutrition among children infected with HIV in sub-Saran Africa published from 2010 to 2021 were included for the first objective. Similarly, studies that identify factors associated with stunting, wasting or under-weight in the respective area published from 2010 to 2021 were included to estimate the pooled effect size of associated factors. In this review, we include articles published in English. Studies that didn't reported neither the prevalence nor associated factors of under-nutrition (stunting, under-weight and wasting) were excluded. Case reports, qualitative studies, and articles without full text were not included in this systematic review and meta-analysis.

\section{Outcomes of measurement}

This study has two main outcomes. The first result was the pooled prevalence of under-nutrition among HIV infected children in sub-Saharan Africa. The second outcome was to identify factors associated with stunting, underweight, and wasting among HIV infected children. In the included studies, the screening for stunting, under-weight, and wasting was performed by height for age- $\mathrm{Z}$ score (HAZ), weight for age - $\mathrm{Z}$ score (WAZ), and weight for height $-Z$ score (WHZ), respectively. The prevalence was measured using the percentage of under-nutrition (stunting, under-weight, and wasting) among HIV positive children. The associated factors with stunting, underweight and wasting were measured in terms of the odds ratio. The odds ratio was calculated from primary studies using two- by- two epidemiological tables.

\section{Search strategy}

Relevant studies were searched from the PubMed / MEDLINE online, Science Direct Hinari web of science, CINHAL, EMBASE, WHO databases. Grey literature was also identified from Google and Google Scholar. The key terms used to retrieve primary studies were Prevalence OR Magnitude AND Under-nutrition OR, Stunting OR Under-weight OR Wasting OR Malnutrition OR Nutritional status AND Human Immunodeficiency Virus (HIV) AND Children OR 'child' OR 'infant' AND Sub-Saharan Africa) for the first objective. We used key terms ((Factors OR determinants OR risk factors OR correlates) AND Under-nutrition OR Underweight OR Wasting OR Stunting /Malnutrition/ AND human immunodeficiency virus (HIV) AND Children AND Sub-Sahara Africa) to search primary studies conducted on factors associated with under-nutrition among HIV infected children (supplementary file five). The last search date was 18 October 2021. The search of the studies was done by JN and BG.

\section{Quality appraisal}

The principal investigator (JN) performed an initial review by title and abstract to eliminate articles that were visibly not important for this review. The full text articles were included if they reported the magnitude or prevalence of under-nutrition (stunting, under-weight or stunting) and/or its associated factors. Two investigators (BG and AM) independently screened the selected full text studies using our eligibility criteria. During the selection process, disagreements between the two authors were resolved by mediation of the fourth reviewer (MM) for the final decision to be included in the analysis.

The quality of the included studies was assessed using the Newcastle-Ottawa quality assessment scale [29]. The tool has three main parts. The first part had five components used to assess the methodological quality of each study. The second part assesses the comparability of primary studies, and the final part of the tool measures the quality of the original articles with respect to their outcome and statistical analysis. Two authors (JN, BG) independently assessed the methodological quality, the quality of the reported data, the stratified data on the types of patients (stunted, under-weight, and wasted), and the clarity of the research design of the included study. Any difference between the two authors during the quality assessment of the primary studies was resolved by taking the average of the two assessment scores. Articles scored 7 and more can be considered as low risk and good to be included for the meta-analysis.

\section{Data extraction}

We used a standardized data extraction format prepared in Microsoft Excel for each type of under-nutrition (stunting, under-weight, wasting) extract all the necessary data. The extraction format contains the name of the first author, publication year, country where the study was conducted, sample size, outcome, response rate, study design, and prevalence of stunting, underweight, wasting for the first objective. For the second objective (factors associated with stunting, underweight, wasting), the Microsoft Excel data extraction format was prepared in the form of a two -by- two table. Categorical variables were tabulated ( $a, b, c$ and $d$ ) with the outcome variable (stunting, underweight, and wasting) during extraction. Data were extracted by two authors (JN, BG) using a standardized data extraction spread sheet. The third and fourth authors (AM, MM) assessed the accuracy of the extracted data.

\section{Data analysis and interpretation}

The data extracted from the Microsoft Excel format were exported to STATA Version 14.0 (software) for analysis. A random effect meta-analysis model was used. The pooled effect size was employed in the form of 
prevalence and odds ratio for all type of under-nutrition (stunting, wasting and under-weight). The Forest plot was used to show the pooled estimate with a $95 \%$ confidence interval (CI). Statistical heterogeneity was evaluated by the $\mathrm{I}^{2}$ test, which shows the level of heterogeneity between studies [30]. Basically, the $\mathrm{I}^{2}$ test doesn't depend on the number of studies incorporated into the study. The heterogeneity of the included studies was interpreted as an $\mathrm{I}^{2}$ value of $25 \%=$ low, $50 \%=\bmod -$ erate, and $75 \%$ and above $=$ high. We also assessed publication bias by visual inspection of funnel plots. To identify the source of heterogeneity, sub-group analysis was performed using country, study design, and year of publication as criteria. Egger's weighted regression test was used to assess publication bias at the $5 \%$ significant level [31, 32]. Finally, for all analyses, $P<0.05$ was considered statistically significant.

\section{Result}

In the initial search, we found a total of 1034 records from the electronic search database of Midline/PubMed,
Science Direct, Hinari, web of science, CINHAL, EMBASE, WHO databases Google, and Google Scholar. About 591 records were excluded due to duplication, and the remaining 443 records were screened. About 323 articles were excluded after reading their title and abstract as we found these articles irrelevant to our review. After the full text review, 82 articles were further excluded with reason. Finally, 38 studies were included in this systematic review and meta-analysis (Fig. 1).

\section{Characteristics of the included articles}

This systematic review and meta-analysis included 38 primary articles with a total of 16,790 study participants published between 2010 and 2021 from more than 16 sub-Saharan African countries [6-8, 22-27, 33-61] (Table 1). All primary studies included in this systematic review and meta-analysis were observational studies conducted in health facilities with a sample size 28 to 3195 from study conducted in South Africa [48] and West Africa [46] respectively. All included studies used WAZ, WHZ, and HAZ scores below - 2 Z- scores

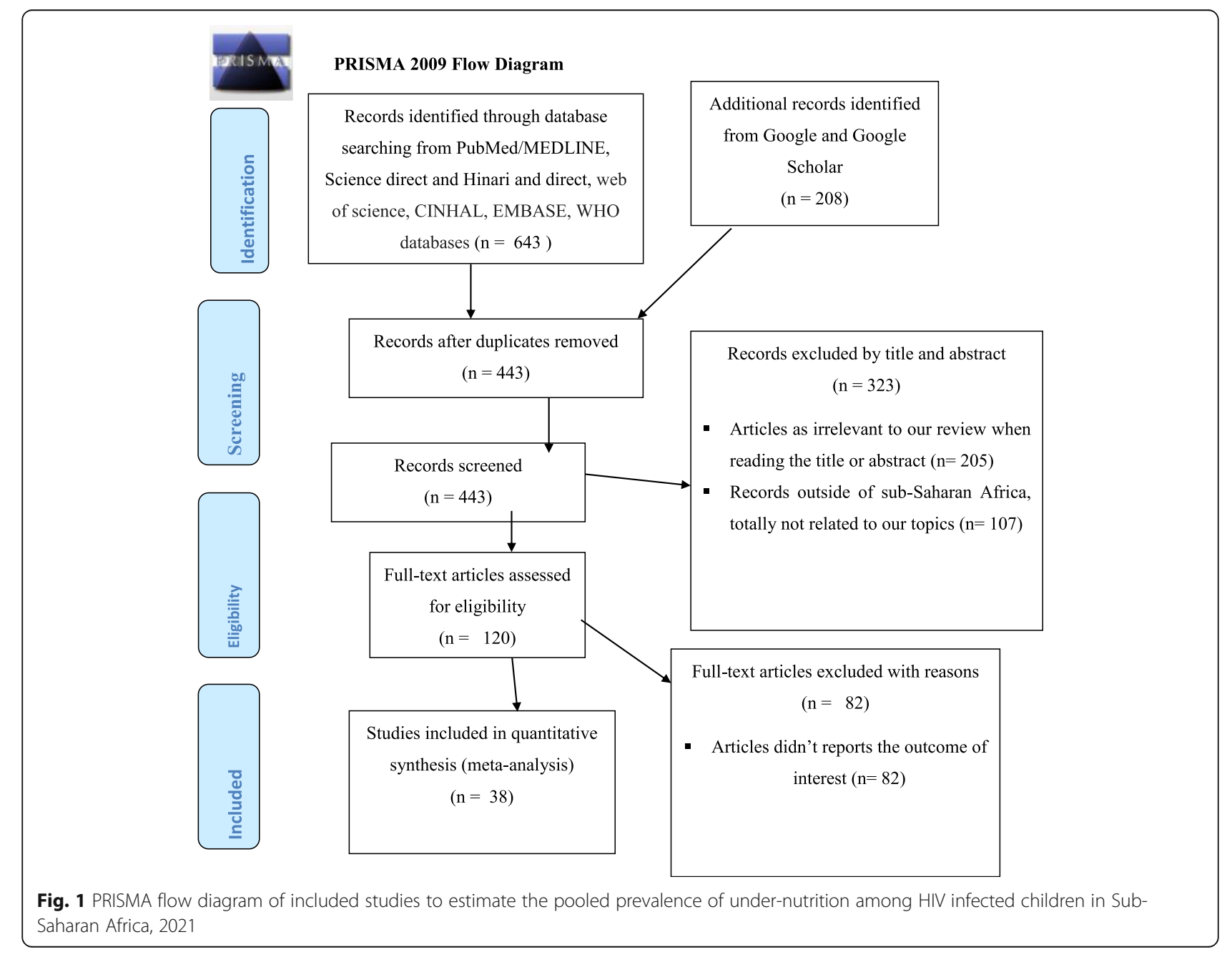


Table 1 Distribution of included studies on the prevalence of under-nutrition among HIV infected children Sub-Saharan Africa, 2021

\begin{tabular}{|c|c|c|c|c|c|c|c|c|}
\hline Author & $\begin{array}{l}\text { Publication } \\
\text { year }\end{array}$ & Country & Sample size & Stunting (\%) & $\begin{array}{l}\text { Under-weight } \\
\text { (\%) }\end{array}$ & Wasting (\%) & Study design & reference \\
\hline Kusum Lata et al & 2020 & Ethiopia & 420 & 60.20 & 41.20 & 21.40 & Cross-sectional & [33] \\
\hline Sunguya et al & 2011 & Tanzania & 213 & 36.60 & 22.10 & 13.60 & Cross-sectional & {$[6]$} \\
\hline Henry Chineme et al & 2014 & Nigeria: & 70 & 48.60 & 58.60 & 31.40 & Cross-sectional & [7] \\
\hline Maura Pedrini et al & 2015 & Mozambique & 140 & 57.40 & 47.10 & 18.60 & Cross-sectional & [34] \\
\hline Jesson et al & 2015 & $\begin{array}{l}\text { Central and } \\
\text { west Africa }\end{array}$ & 1350 & 32.90 & 36.00 & 16.50 & Cross-sectional & [35] \\
\hline Megabiaw et al & 2012 & Ethiopia & 301 & 65.00 & 41.70 & 5.80 & Cross-sectional & {$[36]$} \\
\hline Poda et al & 2017 & Burkina faso & 164 & 29.90 & 11.60 & 10.40 & Cross-sectional & [8] \\
\hline Calixte Ida Penda et al & 2018 & Cameroon & 217 & 63.60 & 37.80 & 18.40 & Cohort & {$[37]$} \\
\hline Bruno F. Sunguya et al & 2014 & Tanzania & 748 & 61.90 & 26.50 & 6.30 & Cross-sectional & {$[38]$} \\
\hline Andreas Chiabi et al & 2012 & Cameroon & 39 & 51.30 & 56.40 & 20.50 & Cohort & [39] \\
\hline A.F. Fagbamigbe et al & 2019 & Nigeria: & 390 & 36.00 & 50.00 & 50.00 & Cross-sectional & {$[40]$} \\
\hline E. A. anigilaje et al & 2015 & Nigeria: & 180 & 54.40 & 12.10 & 33.50 & Cross-sectional & [41] \\
\hline Teklemariam et al & 2015 & Ethiopia & 108 & 49.10 & 51.60 & 31.50 & Cross-sectional & {$[42]$} \\
\hline R. S. Mwiru et al & 2014 & Tanzania & 3144 & 52.00 & 40.00 & 30.00 & Cohort & {$[43]$} \\
\hline Jesson J et al & 2018 & West Africa & 161 & 52.00 & 52.00 & 36.00 & Cross-sectional & [44] \\
\hline Cames et al & 2017 & Senegalese & 244 & 42.00 & & 52.00 & Cross-sectional & [27] \\
\hline Ute D. Feucht et al & 2016 & South Africa & 159 & 73.00 & 50.00 & 19.00 & Cohort & {$[45]$} \\
\hline Julie Jesson. et al & 2019 & West Africa & 3195 & 50.20 & 55.70 & 39.70 & Cohort & {$[46]$} \\
\hline Sofeu CL et al & 2019 & Cameroon & 210 & 77.00 & 53.00 & 47.60 & Cross-sectional & [23] \\
\hline McHenry MS. et al & 2019 & Kenya & 426 & 50.90 & 26.50 & 13.60 & Cohort & [47] \\
\hline Kimani-Murage et al & 2011 & South Africa & 28 & 28.60 & 10.70 & 7.00 & Cross-sectional & [48] \\
\hline Sunguya et al & 2012 & Tanzania & 219 & 40.10 & 6.80 & 10.00 & Cross-sectional & [24] \\
\hline R. Weigel et al & 2010 & Malawi & 363 & 69.10 & 51.80 & & Cohort & [49] \\
\hline Tekleab et al & 2016 & Ethiopia & 202 & 71.30 & 39.50 & 16.30 & Cohort & [50] \\
\hline David Aguilera et al & 2019 & $\begin{array}{l}\text { Equatorial } \\
\text { guinea }\end{array}$ & 213 & 56.30 & 56.30 & 27.70 & Cross-sectional & [25] \\
\hline Julie Jesson et al & 2017 & Mali & 308 & 20.00 & & 31.50 & Cohort & [51] \\
\hline Asiya et.al. & 2018 & Ethiopia & 412 & 13.40 & 21.80 & & Cross-sectional & [22] \\
\hline Haileselassie et al & 2019 & Ethiopia & 376 & 24.70 & & 28.20 & Cross-sectional & {$[52]$} \\
\hline Arinaitwe et al & 2012 & Uganda & 57 & 29.89 & 29.89 & & Cohort & [53] \\
\hline Atnafu Mekonnen et al & 2014 & Ethiopia & 243 & 62.10 & 15.4 & 2.50 & Cross-sectional & [26] \\
\hline Kedir et al & 2014 & Ethiopia & 560 & & 51.6 & & Cohort & [54] \\
\hline Abdulkadir et al & 2014 & Ethiopia & 142 & 46.50 & 40.80 & 31.70 & Cross-sectional & {$[55]$} \\
\hline Arpadi et al & 2019 & Rwanda & 374 & 60.00 & 24.00 & 11.00 & Cross-sectional & {$[56]$} \\
\hline Nalwoga et al & 2010 & Uganda & 31 & 68.00 & 52.00 & 4.00 & Cross-sectional & {$[57]$} \\
\hline S. T. Echendu et al & 2021 & Nigeria & 370 & 27.9 & 15.7 & 13.3 & Cross-sectional & {$[60]$} \\
\hline Dessalegn N. et al & 2021 & Ethiopia & 360 & 30.3 & 19.4 & 19.2 & Cross-sectional & [59] \\
\hline Shiferaw and Gebremedhin & 2020 & Ethiopia & 260 & 33.1 & & 20.0 & Cross-sectional & {$[58]$} \\
\hline Tiruneh et al & 2021 & Ethiopia & 393 & 5.5 & & 36.3 & Cross-sectional & [61] \\
\hline
\end{tabular}

(WHO standard) to screen under-weight, wasting, and stunting, respectively.

The highest prevalence of stunting was reported from a study conducted in Cameron (77.0\%) [23], and the lowest was reported from a study conducted in Ethiopia (5.5\%) [61]. Similarly, the highest prevalence of underweight was reported from a study in Nigeria (58.6\%) [7], and the lowest was from a study in Tanzania (6.8\%) [24]. 
The highest $(52.0 \%)$ and lowest (4\%) prevalence of wasting were also reported from study conducted in Senegalese [27] and Uganda [53] respectively.

\section{Meta-analysis}

A random effect meta-analysis model was used to estimate the pooled prevalence of under-nutrition and its associated factors among HIV infected children in subSaharan Africa. To estimate the prevalence of stunting, 37 studies were included in the analysis; the overall pooled prevalence of stunting was $46.7 \%$ (95\% CI; $40.36-53.07, \mathrm{I} 2=98.7 \%, p<0.01$ ), (Fig. 2 ). Similarly to estimate the prevalence of underweight, 33 studies were included in the analysis, and the total pooled prevalence of under-weight was $35.9 \%$ (95\% CI; 30.79-41.02, $\mathrm{I}^{2}=$ $97.4 \% p<0.01$ ), (Fig. 3). Thirty (34) studies were also included in the analysis to estimate the pooled prevalence of wasting among HIV-infected children; the overall pooled prevalence of wasting was $23.0 \%$ (95\% CI; $18.67-$ 27.42, $\mathrm{I}^{2}=96.9 \%, p<0.01$ ) (Fig. 4). High heterogeneity was observed between studies on the prevalence estimate of stunting, under-weight and wasting. Publication bias was checked using the Egger's test and the results showed that there was no significant publication bias, as evidenced by $p=0.285,0.128$ and 0.058 for stunting, under-weight, and wasting, respectively. We also observed the symmetrical distribution of the funnel plots indicating that publication bias was not significant problem in this meta-analysis (Figs. 5, 6 \& 7).

Subgroup analysis was performed using country, study design, and year of publication to identify the source of heterogeneity.

\section{Subgroup analysis by country}

The highest pooled prevalence of stunting among HIV infected children was in Cameroon, 65.6\% ((95\% CI: 52.8-78.3), $\left.\mathrm{I}^{2}=86.7 \%, P<0.01\right)$ and the lowest was in Nigeria, 41.18\% ((95\% CI: 29.60-25.77), 92.7, <0.01). The highest pooled prevalence estimate of under-weight was in Cameroon, $48.2 \%$ ((95\% CI: 36.1-60.3), $\mathrm{I}^{2}=$ $85.3 \%)$ ) and the lowest was in Tanzania, $24.1 \%$ ((95\% CI; 10.9-37.3), $\left.\mathrm{I}^{2}=97.9 \%, P<0.01\right)$. Similarly, the highest pooled prevalence of wasting was in Nigeria 32.05\% ((95\% CI: 12.49-51.61), 97.5, $P<0.01)$ and the lowest was in Tanzania, $15.1 \%$ (95\% CI: $0.52,29.62$ ), $\mathrm{I}^{2}=98.3 \%$, $P<0.01$ ) (Table 2).

\section{Subgroup analysis by study design}

The prevalence of stunting among HIV infected children was found to be $49.8 \%$ ((95\% CI: 42.5-57.0, $\mathrm{I}^{2}=97.8$, $P<0.01)$ in cross-sectional studies and $48.7 \%(95 \% \mathrm{CI}$; 39.7-57.8), $\left.\mathrm{I}^{2}=97.6, P<0.01\right)$ in cohort studies. The pooled prevalence of under-weight in cross-sectional studies was $35.3 \%$ (95\% CI; 29.70-40.87, $\mathrm{I}^{2}=95.9 \%, P<$ 0.01 ) while in cohort study it was found to be $44.9 \%$ (95\% CI; 35.9-53.7, $\mathrm{I}^{2}=97.2 \%, P<0.01$ ). The prevalence of wasting among HIV infected children was found to be 22.1\% (95\% CI; $\left.16.3-28.0, \mathrm{I}^{2}=96.1, P<0.01\right)$ in crosssectional studies and $27.6 \%\left(95 \% \mathrm{CI} ; 20.99-34.11, \mathrm{I}^{2}=\right.$ $95.3 \%, P<0.01)$ in cohort studies Table 2).

\section{Sub-group analysis by year of publication}

The pooled prevalence of stunting among HIV infected children was found to be $50.5 \%$ ((95\% CI; 44.2-56.8), $\left.\mathrm{I}^{2}=95.9 \%, P<0.01\right)$ from studies published from January 2010-December 2015, but it was $43.79 \%$ (95\% CI;

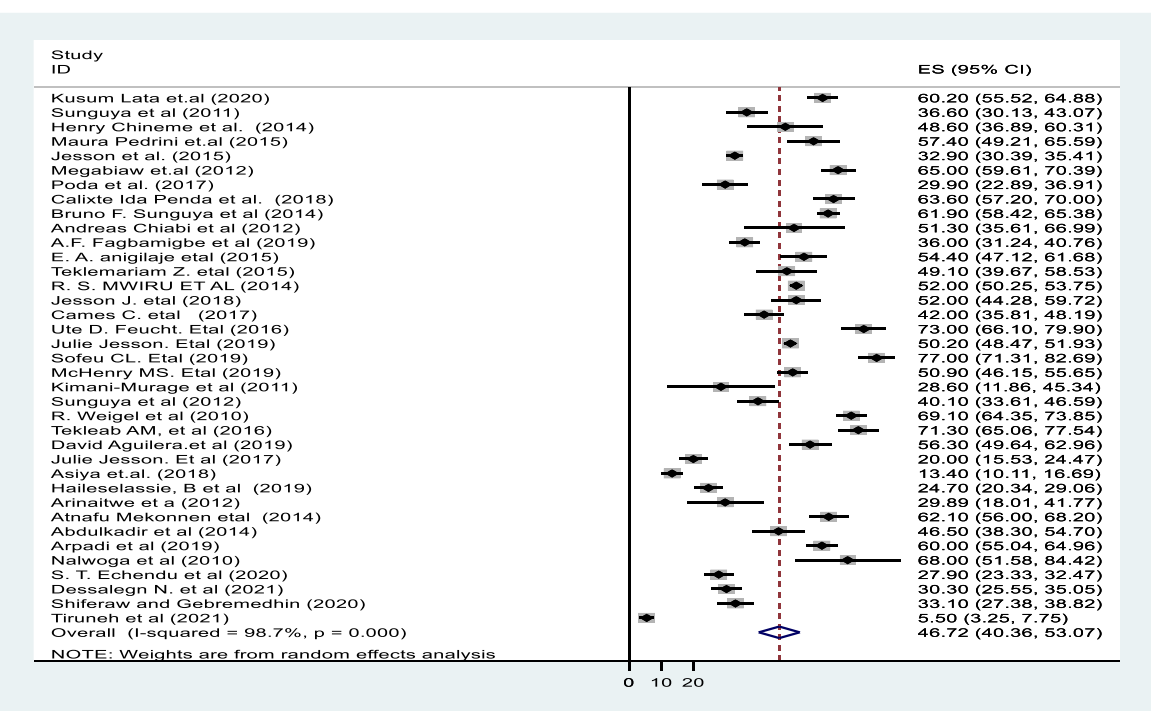

Fig. 2 Forest plot for the pooled prevalence of stunting among HIV infected children in Sub-Saharan Africa, 2021 


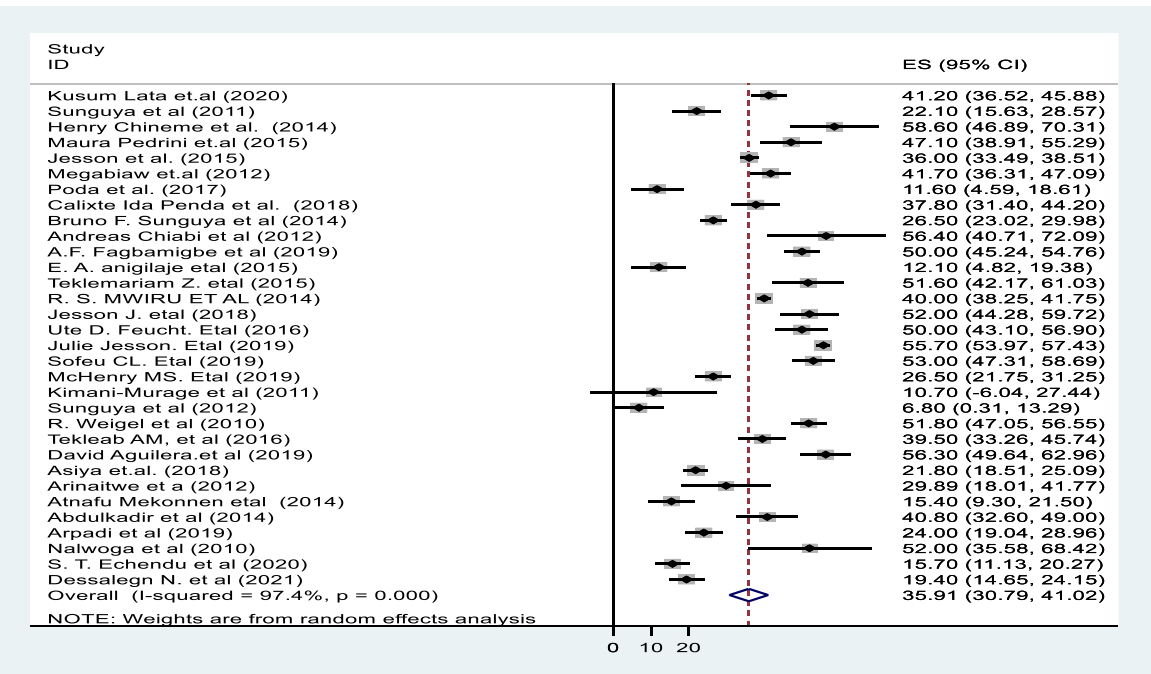

Fig. 3 Forest plot for the pooled prevalence of under-weight among HIV infected children in Sub-Saharan Africa, 2021

33.998-53.575), $\left.\mathrm{I}^{2}=99.1 \%, P<0.01\right)$ from studies published from January 2016-August 2021. The pooled prevalence of under-weight among HIV infected children was found to be $34.8 \%\left(95 \% \mathrm{CI} ; 28.99-40.65, \mathrm{I}^{2}=\right.$ 95.1\%, $P<0.01$ ) from studies published from January 2010-December 2015, while it was 36.9\% (95\% CI; 28.03-45.83, $\mathrm{I}^{2}=98.3 \%, P<0.01$ ) from studies published from January 2016-August 2021. The pooled prevalence of wasting from studies published from January 2010 to December 2015 was found to be $17.7 \%$ (95\% CI; $11.5-$ $\left.23.9, \mathrm{I}^{2}=95.3 \%, P<0.01\right)$ while it was $26.97 \%(95 \% \mathrm{CI}$; $\left.21.37-32.58, \mathrm{I}^{2}=96.8 \%, P<0.01\right)$ from studies published from 2016 to 2021 (Table 2).

\section{Factors associated with under-nutrition among HIV infected children}

\section{Factors associated with stunting}

During the review process, we identified numerous factors associated with stunting from the primary studies. Variables reported as a significant association with stunting in at least three primary studies were included in this metal analysis. Accordingly, advanced WHO HIV/AIDS

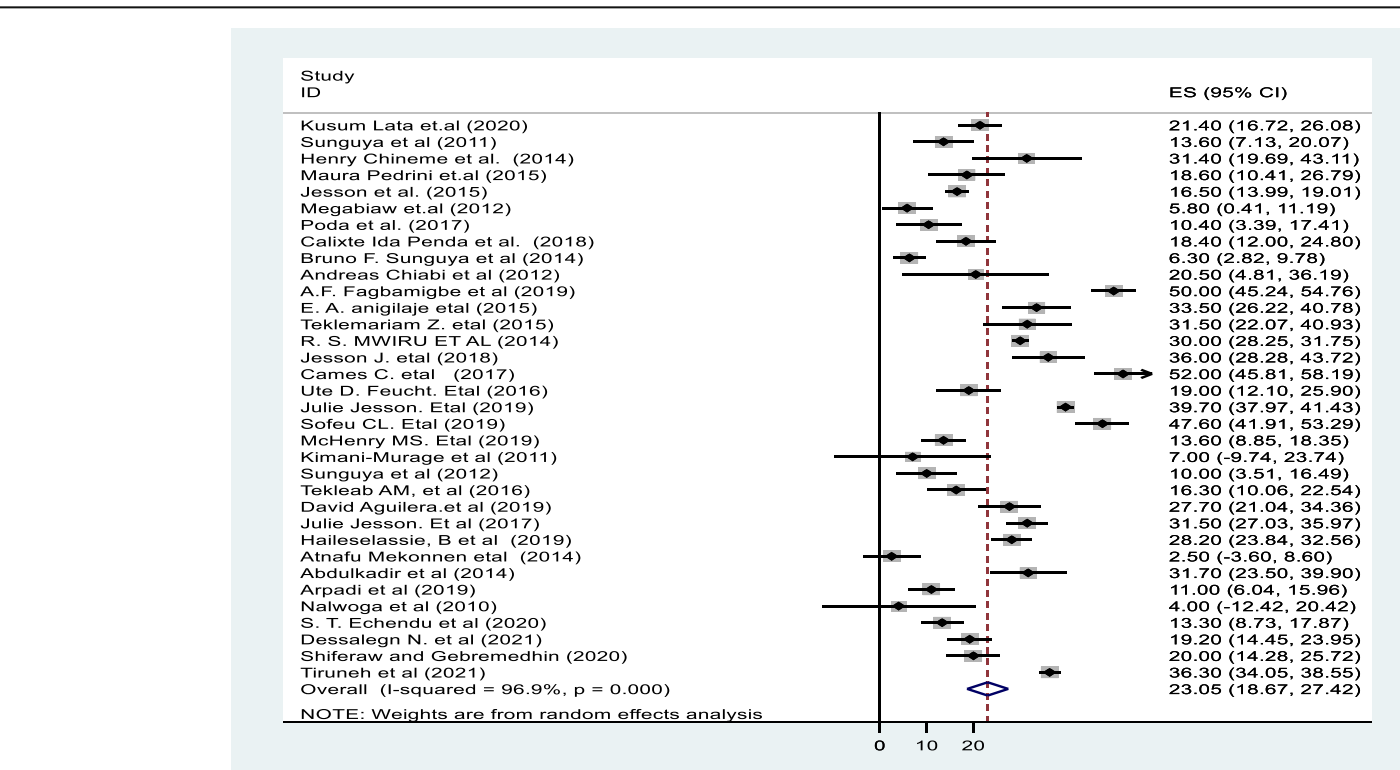

Fig. 4 Forest plot for the pooled prevalence of wasting among HIV infected children in Sub-Saharan Africa, 2021 


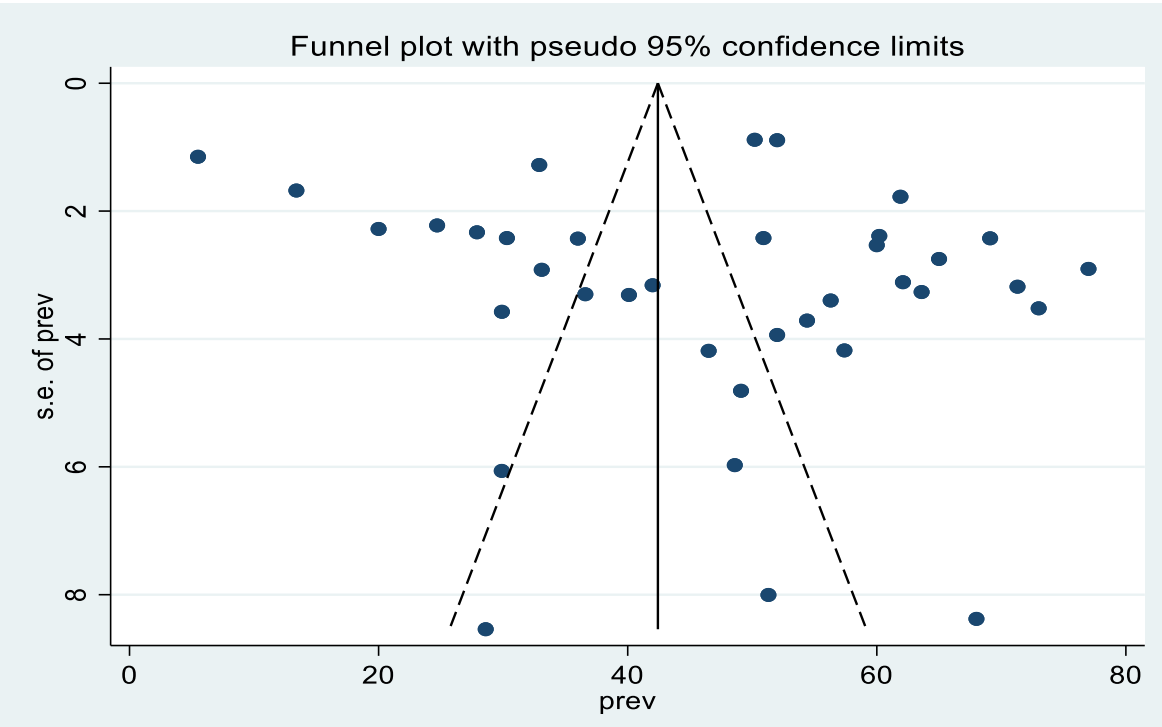

Fig. 5 Funnel plot showing the symmetric distribution of articles on pooled prevalence stunting among HIV infected children in Sub-Saharan Africa, 2021

clinical staging and household food insecurity were found to be a significant association with stunting (Table 3, supplementary file three).

Advanced WHO HIV/AIDS clinical staging was reported as a factor associated with stunting among HIVinfected children by three primary studies $[6,38,52]$. A total of 1337 participants were included to analyze the association between WHO HIV/AIDS clinical staging (III\&IV) and stunting among HIV infected children. The pooled odds ratio showed that children who had an advanced WHO HIV/AIDS clinical stage were 6.74 times more odds of stunting than their counterpart $\left[\mathrm{OR}=6.74\right.$ (95\%: 1.747, 26.021), $\left.\mathrm{I}^{2}=94.7 \%, P<0.01\right]$ (Table 3, supplementary file three).

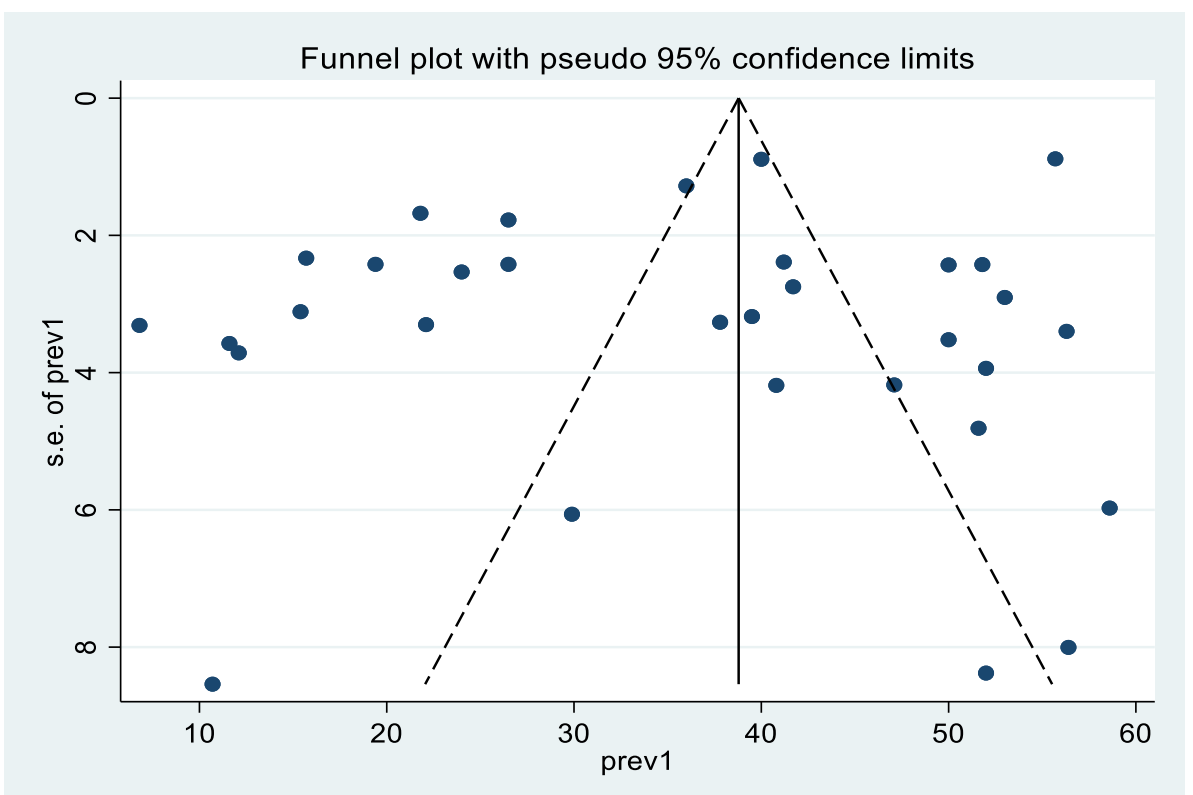

Fig. 6 Funnel plot showing the symmetric distribution of articles on pooled prevalence of under-weight among HIV infected children in SubSaharan Africa, 2021 


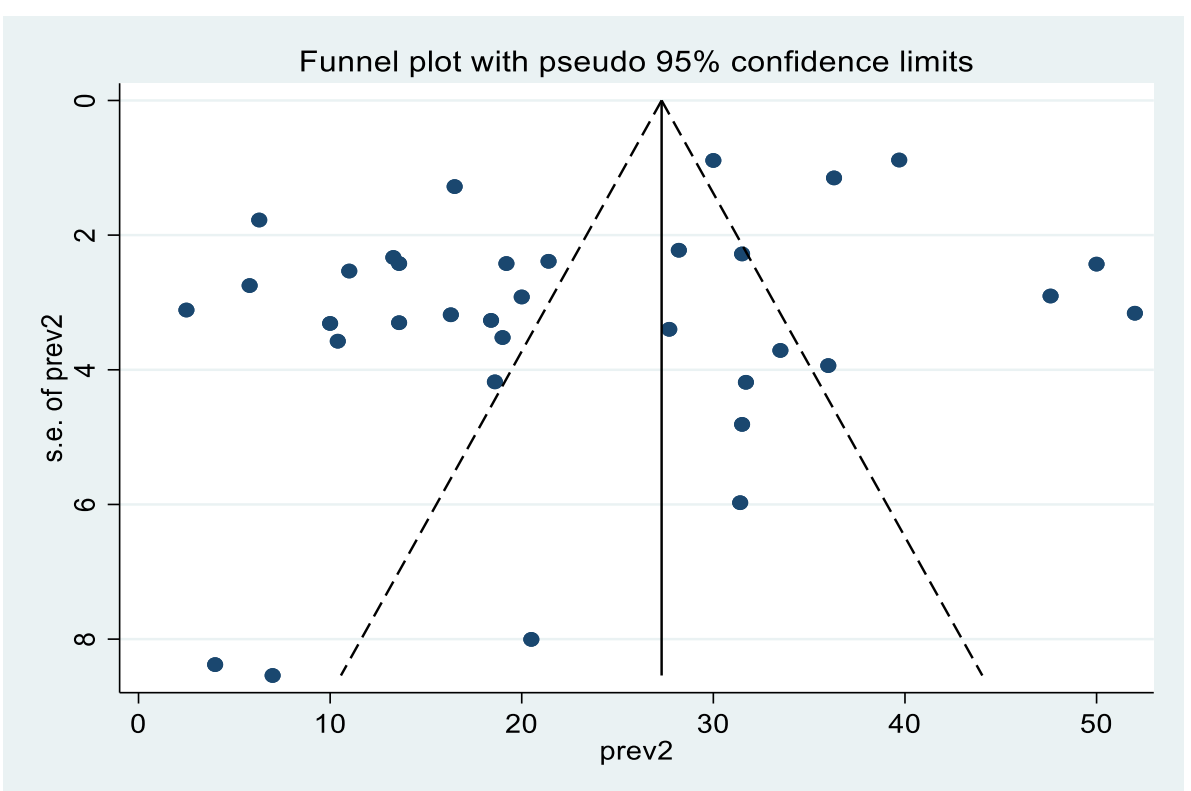

Fig. 7 Funnel plot showing the symmetric distribution of articles on pooled prevalence of wasting among HIV infected children in Sub-Saharan Africa, 2021

Household food insecurity was reported to be a factor associated with stunting by four primary studies included in this review [6, 24, 38, 52]. A total of 1556 children were included to analyze the association between household food insecurity and stunting among HIV infected children. The pooled odds ratio showed that children in food-insecure households were 5.92 times more likely to develop stunting than children in foodsecure households $\left[\mathrm{OR}=5.92(95 \%\right.$ CI $3.9-, 8.87), \mathrm{I}^{2}=$ $55.7 \%, P=0.079$ ] (Table 3, supplementary file three).

Table 2 Summary of subgroup analysis for the prevalence of stunting, under-weight and wasting among HIV infected children in Sub-Saharan Africa, 2021

\begin{tabular}{|c|c|c|c|c|}
\hline Type & Feature & $\begin{array}{l}\text { Pooled prevalence of stunting, } \\
\%\left(95 \% \mathrm{Cl}, \mathrm{I}^{2}, P \text { value }\right)\end{array}$ & $\begin{array}{l}\text { Pooled prevalence of under- } \\
\text { weight, } \%\left(95 \% \mathrm{Cl}, \mathrm{I}^{2}, \mathrm{P} \text { value }\right)\end{array}$ & $\begin{array}{l}\text { Pooled prevalence of wasting, } \\
\%\left(95 \% \mathrm{Cl}, \mathrm{I}^{2}, \mathrm{P} \text { value }\right)\end{array}$ \\
\hline \multirow{15}{*}{$\begin{array}{l}\text { Sub-group analysis } \\
\text { by country }\end{array}$} & Ethiopia & $41.83(26.83-56.84,99.1,<0.01)$ & $33.62(25.04-42.20,95.0,<0.01)$ & $21.24(13.56-28.93,95.9,<0.01)$ \\
\hline & Tanzania & $48.10(39.05-57.15,95.4,<0.01)$ & $24.11(10.88-37.33,97.9,<0.01)$ & $15.07(0.52-29.62,98.3,<0.01)$ \\
\hline & Nigeria & $41.18(29.60-25.77,92.7,<0.01)$ & $33.83(11.81-55.85,98,<0.01)$ & $32.05(12.49-51.61,97.5,<0.01)$ \\
\hline & Mozambique* & $57.40(49.21-65.59,-)$ & $47.10(38.91-55.29,-)$ & $18.60(10.41-26.79,-)$ \\
\hline & Central Africa* & $32.90(30.39-35.40,-)$ & $36.00(33.49-38.51,-)$ & $16.50(13.99-19.00,-)$ \\
\hline & Burkina Faso* & $29.90(22.89-36.90,-)$ & $11.60(4.59-18.61,-)$ & $10.40(3.39-17.41,-)$ \\
\hline & Cameroon & $65.56(52.82-78.29,86.7,<0.01)$ & $48.16(36.06-60.26,85.3,<0.01)$ & $29.24(7.00-51.47,95.8,<0.01)$ \\
\hline & Senegalese* & $42.00(35.80-48.19,-)$ & - & $52.00(45.81-58.19,-)$ \\
\hline & South Africa & $51.48(7.99-94.97,95.7,<0.01)$ & $31.12(7.36-69.60,94.5,<0.01)$ & $15.52(4.85-26.19,40.7,0.194)$ \\
\hline & Kenya* & $50.90(46.15-55.64,-)$ & $26.50(21.75-31.25,-)$ & $13.60(8.85-18.35,-)$ \\
\hline & Malawi* & $69.10(64.35-73.85,-)$ & $51.80(47.05-56.55,-)$ & - \\
\hline & Equatorial Guinea* & $56.30(49.64-62.96,-)$ & $56.30(49.64-62.96,-)$ & $27.70(21.04-34.36,-)$ \\
\hline & Mali* & $20.00(15.53-24.47,-)$ & - & $31.50(27.03-35.97,-)$ \\
\hline & Uganda & $48.51(11.17-85.84,92.6,<0.01)$ & $40.19(18.57-61.80,78.1,<0.01)$ & $4.00(12.42-20.42,-)$ \\
\hline & Rwanda* & $60.00(55.03-64.96,-)$ & $24.0(19.04-28.97,-)$ & $11.00(6.04-5.97,-)$ \\
\hline \multirow{2}{*}{$\begin{array}{l}\text { Sub-group analysis } \\
\text { by study design }\end{array}$} & Cross-sectional & $49.8(42.5-57.0,97.8)$ & $35.29(29.70-40.87,95.9)$ & $22.15(16.29-28.00,96.1)$ \\
\hline & Cohort & $48.7(39.7-57.8,97.6)$ & $44.89(35.93-53.86,97.2)$ & $27.55(20.99-34.11,95.3)$ \\
\hline \multirow{2}{*}{$\begin{array}{l}\text { Sub-group analysis } \\
\text { by publication year }\end{array}$} & January 2010-december 2015 & $50.48(44.19-56.77,95.9,<0.01)$ & $34.82(28.99-40.65,95.1,<0.01)$ & $17.67(11.45-23.89,95.3,<0.01)$ \\
\hline & January 2016-aguest 2021 & $43.79(33.998-53.575,99.1,<0.01)$ & $36.93(28.03-45.83,98.3,<0.01)$ & $26.97(21.37-32.58,96.8,<0.01)$ \\
\hline
\end{tabular}


Table 3 Summary of factors associated with under-nutrition among HIV infected children in Sub-Saharan Africa, 2021

\begin{tabular}{|c|c|c|c|c|c|c|}
\hline \multirow{2}{*}{$\begin{array}{l}\text { Types of } \\
\text { Under-nutrition }\end{array}$} & \multirow[t]{2}{*}{ Variables } & \multirow{2}{*}{$\begin{array}{l}\text { Number } \\
\text { of studies }\end{array}$} & \multirow{2}{*}{$\begin{array}{l}\text { Studies includes the } \\
\text { analysis }\end{array}$} & \multirow{2}{*}{$\begin{array}{l}\text { Odds ratio } \\
\text { with } 95 \% \mathrm{Cl}\end{array}$} & \multicolumn{2}{|c|}{ Heterogeneity } \\
\hline & & & & & $\left(1^{2}\right)$ & P-value \\
\hline \multirow[t]{2}{*}{ Stunting } & WHO HIV/AIDS clinical staging & 3 & $\begin{array}{l}\text { Haileselassie, B et al., } 2019 \\
\text { Sunguya et al., } 2011 \\
\text { Bruno F. Sunguya et al., } 2014\end{array}$ & $6.74(1.75,26.02)$ & $94.7 \%$ & $P<0.01$ \\
\hline & Household food insecurity & 4 & $\begin{array}{l}\text { Haileselassie, B et al.,2019 } \\
\text { Sunguya et al., } 2011 \\
\text { Bruno F. Sunguya et al., } 2011 \\
\text { Sunguya et al., } 2012\end{array}$ & $5.92(3.9,8.87)$ & $55.7 \%$ & $P=0.079$ \\
\hline \multirow[t]{2}{*}{ Under-weight } & low family income & 4 & $\begin{array}{l}\text { Kusum Lata et.al, } 2020 \\
\text { Megabiaw et.al, } 2012 \\
\text { Sunguya et al., } 2012 \\
\text { Asiya et.al, } 2018\end{array}$ & $4.74(2.6,8.61)$ & $31.2 \%$ & $P=0.225$ \\
\hline & Feeding frequency & 3 & $\begin{array}{l}\text { Kusum Lata et.al, } 2020 \\
\text { Sunguya et al., } 2011 \\
\text { Bruno F. Sunguya et al., } 2014\end{array}$ & $0.32(0.17,0.6)$ & $69.8 \%$ & $P=0.037$ \\
\hline \multirow[t]{2}{*}{ Wasting } & Diarrhoea & 3 & $\begin{array}{l}\text { Kusum Lata et.al, } 2020 \\
\text { Sunguya et al. } 2011 \\
\text { Haileselassie, B et al., } 2019\end{array}$ & $4.12(2.88,5.89)$ & $0.0 \%$ & $P=0.386$ \\
\hline & Anemia & 3 & $\begin{array}{l}\text { Haileselassie, B et al., } 2019 \\
\text { R. S. MWIRU ET AL } 2014 \\
\text { Julie Jesson. Et al } 2017\end{array}$ & $2.86(1.64,5.0)$ & $74.8 \%$ & $P=0.019$ \\
\hline
\end{tabular}

\section{Factors associated with under-weight}

To identify factors associated with under-weight, we reviewed more than 13 primary studies and identified numerous factors for the occurrence of under-weight among HIV infected children. Variables reported as a significant association with under-weight in at least three primary studies were included in this meta-analysis. As a result, low family income and feeding frequency were significantly associated with under-weight (Table 3, supplementary file three).

Family economic status was identified as a factor associated with underweight in four primary articles included in this meta-analysis [22, 24, 33, 36]. A total of 1352 participants were included to analyze the association between monthly family income and under-weight. The odds of under-weight among HIV infected children with low family income were 4.74 times higher than their counterparts $[\mathrm{OR}=4.737$ (95\% CI: 2.605, 8.614), $\left.\mathrm{I}^{2}=31.2 \%, P=0.225\right]$ (Table 3, supplementary file three).

Feed frequency was identified as a factor associated with under-weight among HIV infected children in three primary studies included in the meta-analysis $[6,33,38]$ with a total of 1,381 study participants. The odds of under-weight among HIV infected children who feed 4 times or more per $24 \mathrm{~h}$ were $67.7 \%$ less odds of underweight than children feeding less than 4 times per $24 \mathrm{~h}$ [OR $=0.323$ (95\% CI: 0.172, 0.605), $\mathrm{I}^{2}=69.8 \%, P=0.037$ ] (Table 3, supplementary file three).

\section{Factors associated with wasting}

In this review, we find numerous factors associated with wasting reported in different primary studies. Variables reported as a significant association with wasting in at least three primary studies were included in this metal analysis. Accordingly, anemia and diarrhoea in the previous month were found to have significant association with wasting among HIV-infected children in subSaharan Africa (Table 3, supplementary file three).

Three primary articles reported anemia as a factor for wasting among HIV-infected children with a total of 3828 samples [43, 51, 52]. The odds of wasting among anemic HIV positive children were 2.86 times higher than among non-anemic HIV positive children [OR = 2.860 (95\% CI: 1.636, 5.000), $\mathrm{I}^{2}=74.8 \%, P=0.019$ ] (Table 3 , supplementary file three).

Diarrhoea in the previous month was identified as a factor associated with wasting in three primary studies included in this review $[6,33,52]$. To see the association between Diarrhoea and wasting, 1009 study participants were included in the analysis. Consequently, children who had diarrhoea in the previous month had 4.1 times more odds of wasting than children with no diarrhoea in the previous month $[\mathrm{OR}=4.117$ (95\% CI: 2.876, 5.894), $\left.\mathrm{I}^{2}=0.0 \%, P=0.386\right]$ (Table 3 , supplementary file three).

\section{Discussion}

Most HIV infected children have an episode of severe malnutrition as their first AIDS-defining illness. Undernutrition is an important factor which might predict disease progression of HIV-infected individuals. It also results in higher risk of morbidity and mortality in both HIV-infected adults and children. This review was conducted to show the pooled prevalence and associated factors of under-nutrition (stunting, under-weight, and 
wasting) among HIV infected children in sub-Saharan African countries. This is the first systematic review and meta-analysis on under-nutrition (stunting, underweight and wasting) among HIV infected children in sub-Saharan African region.

The results of this meta-analysis showed that the pooled prevalence of stunting was $46.7 \%(95 \% \mathrm{CI}$; 40.36-53.07, $\left.\mathrm{I}^{2}=98.7 \%, p<0.01\right)$ among HIV infected children in sub-Saharan Africa. This finding was in line with a study conducted in India (46.37\%) [62] and metaanalysis conducted in east Africa (49.68\%) [63]. However, it was low compared to a study conducted in south India (58\%) [64]. The discrepancy might be due to the difference in the number of study participants used by studies. It was higher than the large-scale study conducted among HIV infected adolescents (41\%) in the less developed region of the world [65]. The finding was also higher than the WHO estimate of stunting (32.5\%) in children regardless of HIV status in African [3]. This is expected since under-nutrition is more prevalent in HIV infected children than uninfected children [8].

The pooled prevalence of underweight was 35.9\% (95\% CI; $30.79-41.02, \mathrm{I}^{2}=97.4 \% p<0.01$ ), in this metaanalysis. This finding was lower than a systematic review and meta-analysis study in east Africa (41.63) [63]. It was also lower compared to studies conducted in south India (65\%) [64] and India (55.2\%) [62]. The discrepancy might be due to the background rate of HIV infection and under-nutrition in the area. In this meta-analysis, the pooled prevalence of wasting was $23.0 \%$ (95\% CI; 18.67-27.42, $\left.\mathrm{I}^{2}=96.9 \%, p<0.01\right)$. Almost similar report was found in systematic review and meta-analysis study conducted in east Africa [63] . This result was higher than studies conducted in south India (16\%) [64], in the less developed region of the world (14.5\%) [65] and WHO estimate of wasting (6.4\%) in Africa [3]. However, it was lower compared to the study finding in India (34.3\%) [62]. The reason for the discrepancy may be the difference in sample size and study population.

Regarding factors associated with under-nutrition, advanced WHO HIV/AIDS clinical staging and household food insecurity were significantly associated with stunting among HIV infected children. Family economic status and feeding frequency were found to be significantly associated with underweight. Anemia and diarrhoea in the previous month were also significantly associated with wasting among HIV infected children in subSaharan Africa.

The odd of stunting among children with advanced WHO HIV/AIDS clinical staging was 6.7 times higher than their counterparts. Advanced AIDS disease reduces the food appetite of the child due to opportunistic infection that leads to under-nutrition. Children living in food-insecure households were 5.9 times higher odds of stunting than children living in food-secure households. The reason might be that there may be chronic starvation in food-insecure households that easily lead to stunting.

Children whose families had low economic status were 4.7 times more likely to be underweight compared to their counterparts. The reason might be that children who have low family economic status may face poor food access and a lack of a balanced diet results underweight. HIV infected children who feed 4 times or more per day had $67.8 \%$ less odds of under-weight than children feeding less than 4 times per $24 \mathrm{~h}$. This might be due to that low frequency and diversity of feeding demonstrate poor access to food and low micronutrient intake which lead to under-weight [66].

The odds of wasting among HIV positive children who had anemia were 2.9 times higher than among nonanemic HIV positive children. The reason might be that a decrease in the supply of nitrate to the tissue as a result of a decreased blood supply results the child become wasting. Children who had diarrhoea in the previous month had 4.1 times more odds of wasting than children who did not have diarrhoea in the previous month. This might be due to that mal-absorption of nitrate related to frequent loss of stool leading to wasting.

\section{Limitation of the study}

Most primary studies included in this systematic review and meta-analysis were cross-sectional studies which difficulty to established cause-effect relation-ships. The other limitation of this study is the presence of significant heterogeneity between the primary studies and did not consider articles published other than English language.

\section{Conclusion}

This review showed that the prevalence of under- nutrition among HIV infected children was high. Almost half of the HIV infected children became stunted and more than $20 \%$ had wasted. The review also showed that two out of five HIV infected children were underweight. Advanced WHO HIV/AIDS clinical staging and household food insecurity were associated with the occurrence of stunting. Low family economic status and low feeding frequency were also associated with under-weight among HIV infected children. Furthermore, anemia and diarrhoea in the previous month were significantly associated with wasting among HIV infected children in subSaharan Africa. Nutritional assessment and interventions should give great emphasis during HIV care of children in the ART clinic.

\section{Abbreviations}

AIDS: Acquired Immune Deficiency Syndrome; ART: Anti-Retroviral Therapy; HIV: Human Immunodeficiency Virus; WHO: World Health Organizations; 
OR: odds ratio; Cl: confidence interval; WAZ: weight for age z score; WHZ: weight for height z score; HAZ: height for age z score

\section{Supplementary Information}

The online version contains supplementary material available at https://doi. org/10.1186/s13690-021-00785-z.

\section{Additional file 1 \\ Additional file 2. \\ Additional file 3. \\ Additional file 4. \\ Additional file $\mathbf{5}$.}

\section{Acknowledgements}

Not applicable.

\section{Authors' contributions}

JN and BG conceived the idea, participated in data extraction, analysis, and draft writing. AM and MM participated in the analysis, manuscript preparation, and revision. All authors read and approved the final version of the manuscript to be considered for publication.

\section{Funding}

Not applicable.

\section{Availability of data and materials}

The data used for this study are available and can be accessed from the corresponding author using 'jemberu2123@gmail.com'with reasonable request.

\section{Declarations}

\section{Ethics approval and consent to participate}

Not applicable.

\section{Consent for publication}

Not applicable.

\section{Competing interests}

All authors declare that they have no competing interests.

\section{Author details}

${ }^{1}$ Department of Nursing College of Health Sciences and Medicine, Dilla University, Dilla, Ethiopia. ${ }^{2}$ Department of Psychiatry College of Health Science and Medicine, Dilla University, Dilla, Ethiopia. ${ }^{3}$ Department of Reproductive Health School of Public Health, College of Health Science and Medicine, Dilla University, Dilla, Ethiopia. ${ }^{4}$ Department of Nursing College of Health Sciences and Medicine, Debre Markos University, Debre Markos, Ethiopia.

Received: 22 September 2021 Accepted: 28 December 2021

Published online: 05 January 2022

\section{References}

1. Gedle D, Gelaw B, Muluye D, Mesele M. Prevalence of malnutrition and its associated factors among adult people living with HIV/AIDS receiving antiretroviral therapy at Butajira hospital, southern Ethiopia. BMC Nutri. 2015; 1(1):1-11. https://doi.org/10.1186/2055-0928-1-5.

2. UNICEF.: UNICEF data: Monitoring the situation of children and women. 2020. Accessed 7 July 2020

3. Organization WH. UNICEF/WHO/the World Bank Group joint child malnutrition estimates: levels and trends in child malnutrition: key findings of the. 2020th ed; 2020.

4. UNCEF: Children, food and nutrition growing well in a changing world. In. 2019.

5. Friedman JF, Kwena AM, Mirel LB, Kariuki SK, Terlouw DJ, Phillips-Howard PA, et al. Malaria and nutritional status among pre-school children: results from cross-sectional surveys in western Kenya. Am J Trop Med Hyg. 2005; 73(4):698-704. https://doi.org/10.4269/aitmh.2005.73.698.

6. Sunguya BF, Poudel KC, Otsuka K, Yasuoka J, Mlunde LB, Urassa DP, et al. Undernutrition among HIV-positive children in Dar Es Salaam, Tanzania: antiretroviral therapy alone is not enough. BMC Public Health. 2011;11(1): 869. https://doi.org/10.1186/1471-2458-11-869.

7. Anyabolu HC, Adejuyigbe EA, Adeodu OO. Undernutrition and anaemia among HAART-naïve HIV infected children in Ile-Ife, Nigeria: a casecontrolled, hospital based study. Pan Afr Med J. 2014;18(1). https://doi.org/1 0.11604/pamj.2014.18.77.3746.

8. Poda GG, Hsu C-Y, Chao JC. Malnutrition is associated with HIV infection in children less than 5 years in Bobo-Dioulasso City, Burkina Faso: A casecontrol study. Medicine. 2017;96(21). https://doi.org/10.1097/MD. 0000000000007019.

9. Black MM, Walker SP, Wachs TD, Ulkuer N, Meeks Gardner J. Maternal and Child Undernutrition 4 Maternal and child undernutrition: effective action at national level. Commentary. Policies to reduce undernutrition include child development. Lancet (British edition). 2008;371(9611):455. https://doi.org/1 0.1016/S0140-6736(08)60215-9.

10. Organization WH. WHO, UNICEF and SCN informal consultation on community-based Management of Severe Malnutrition in children. SCN Nutri Policy Paper. 2006;21.

11. UNICEF: The faces of malnutrition. Accessed July 2020.

12. Victora CG, Adair L, Fall C, Hallal PC, Martorell R, Richter L, et al. Maternal, group CUS: maternal and child undernutrition: consequences for adult health and human capital. Lancet. 2008;371(9609):340-57. https://doi.org/1 0.1016/S0140-6736(07)61692-4

13. Heikens GT, Bunn J, Amadi B, Manary M, Chhagan M, Berkley JA, et al. Case management of HIV-infected severely malnourished children: challenges in the area of highest prevalence. Lancet. 2008;371(9620):1305-7. https://doi. org/10.1016/S0140-6736(08)60565-6.

14. Byron E, Gillespie S, Nangami M. Integrating nutrition security with treatment of people living with HIV: lessons from Kenya. Food Nutr Bull. 2008:29(2):87-97. https://doi.org/10.1177/156482650802900202.

15. Sunguya B, Koola J, Atkinson S. Infection associated with severe malnutrition among hspitalised children in East Africa. Tanzania J Health Res. 2006;8(3). https://doi.org/10.4314/thrb.v8i3.45120.

16. Bachou H, Tylleskär T, Downing R, Tumwine JK. Severe malnutrition with and without HIV-1 infection in hospitalised children in Kampala, Uganda: differences in clinical features, haematological findings and CD4+ cell counts. Nutr J. 2006;5(1):27. https://doi.org/10.1186/1475-2891-5-27.

17. Johann-Liang R, O'Neill L, Cervia J, Haller I, Giunta Y, Licholai T, et al. Energy balance, viral burden, insulin-like growth factor-1, interleukin-6 and growth impairment in children infected with human immunodeficiency virus. Aids. 2000;14(6):683-90. https://doi.org/10.1097/ 00002030-200004140-00007

18. Trehan I, O'Hare BA, Phiri A, Heikens GT. Challenges in the management of HIV-infected malnourished children in sub-Saharan Africa. AIDS Res Treatment. 2012;2012:1-8. https://doi.org/10.1155/2012/790786.

19. Anabwani G, Navario P. Nutrition and HIV/AIDS in sub-Saharan Africa: an overview. Nutrition. 2005;21(1):96-9. https://doi.org/10.1016/j.nut.2004.09. 013.

20. Black RE, Morris SS, Bryce J. Where and why are 10 million children dying every year? Lancet. 2003;361(9376):2226-34. https://doi.org/10.1016/S01406736(03)13779-8.

21. Hesseling AC, Westra A, Werschkull H, Donald P, Beyers N, Hussey G, et al. Outcome of HIV infected children with culture confirmed tuberculosis. Arch Dis Child. 2005;90(11):1171-4. https://doi.org/10.1136/adc.2004.070466.

22. Jeylan A, Mohammed E, Girma A. Magnitude of stunting, thinness and associated factors among HIV positive children attending chronic HIV care and support in Adama Hospital Medical College, Adama, Oromia Regional State, Ethiopia. Int J Health Sci Res. 2018:8(11)

23. Sofeu CL, Tejiokem MC, Penda Cl, Protopopescu C, Ateba Ndongo F, Tetang Ndiang $S$, et al. Early treated HIV-infected children remain at risk of growth retardation during the first five years of life: results from the ANRSPEDIACAM cohort in Cameroon. PLoS One. 2019;14(7):e0219960. https://doi. org/10.1371/journal.pone.0219960.

24. Sunguya BF, Poudel KC, Mlunde LB, Otsuka K, Yasuoka J, Urassa DP, et al. Ready to use therapeutic foods (RUTF) improves undernutrition among ART-treated, HIV-positive children in Dar Es Salaam, Tanzania. Nutr J. 2012; 11(1):60. https://doi.org/10.1186/1475-2891-11-60. 
25. Aguilera-Alonso D, Grasa C, Cervantes Hernández E, Eyene Bacale Ayeto M, Endje Moliko A, García B, et al. nutritional, clinical and immunological status of children at HIV diagnosis in the continental region of Equatorial Guinea. Trop Med Int Health. 2020;25(2):248-54. https://doi.org/10.1111/tmi.13325.

26. Tekleab AM: Assessment of magnitude and factors affecting nutritional status of HIV infected under-five children at five public hospitals in Addis Ababa and its programmatic implication. Addis Ababa University; 2014.

27. Cames C, Pascal L, Diack A, Mbodj H, Ouattara B, Diagne NR, et al. Risk factors for growth retardation in HIV-infected Senegalese children on antiretroviral treatment. Pediatr Infect Dis J. 2017;36(4):e87-92. https://doi. org/10.1097/INF.0000000000001454.

28. Liberati A, Altman DG, Tetzlaff J, Mulrow C, Gøtzsche PC, loannidis JP, et al The PRISMA statement for reporting systematic reviews and meta-analyses of studies that evaluate health care interventions: explanation and elaboration. J Clin Epidemiol. 2009;62(10):e1-e34. https://doi.org/10.1016/j. jclinepi.2009.06.006.

29. W PJ, Losos M, Tugwell P. The Newcastle-Ottawa scale (NOS) for assessing the quality of nonrandomised studies in meta-analyses. Ottawa: Ottawa Hospital Research Institute; 2011.

30. Rücker G, Schwarzer G, Carpenter JR, Schumacher M. Undue reliance on I 2 in assessing heterogeneity may mislead. BMC Med Res Methodol. 2008;8(1): 79. https://doi.org/10.1186/1471-2288-8-79.

31. Sterne JA, Egger M. Funnel plots for detecting bias in meta-analysis: guidelines on choice of axis. J Clin Epidemiol. 2001;54(10):1046-55. https:// doi.org/10.1016/S0895-4356(01)00377-8.

32. Egger M, Smith GD, Schneider M, Minder C. Bias in meta-analysis detected by a simple, graphical test. Bmj. 1997;315(7109):629-34. https://doi.org/1 0.1136/bmj.315.7109.629.

33. Lata K, Beyene W. Factors associated with nutritional status of human immunodeficiency virus infected children Hawassa, Ethiopia. Int J Health Sci Res. 2020;10(5):50-9.

34. Pedrini M, Moraleda C, Macete E, Gondo K, Brabin BJ, Menéndez C. Clinical, nutritional and immunological characteristics of HIV-infected children in an area of high HIV prevalence. J Trop Pediatr. 2015;61(4):286-94. https://doi. org/10.1093/tropej/fmv038.

35. Jesson J, Masson D, Adonon A, Tran C, Habarugira C, Zio R, et al. Prevalence of malnutrition among HIV-infected children in central and west-African HIV-care programmes supported by the growing up Programme in 2011: a cross-sectional study. BMC Infect Dis. 2015;15(1):216. https://doi.org/10.1186/ s12879-015-0952-6.

36. Megabiaw B, Wassie B, Rogers NL. Malnutrition among HIV-positive children at two referral hospitals in Northwest Ethiopia. Ethiop J Health Biomed Sci. 2012;5:3-10.

37. Penda Cl, Moukoko ECE, Nolla NP, Evindi NOA, Ndombo PK. Malnutrition among HIV infected children under 5 years of age at the Laquintinie hospital Douala, Cameroon. Pan Afr Med J. 2018;30:91. https://doi.org/10.11 604/pamj.2018.30.91.15832

38. Sunguya BF, Poudel KC, Mlunde LB, Urassa DP, Yasuoka J, Jimba M. Poor nutrition status and associated feeding practices among HIV-positive children in a food secure region in Tanzania: a call for tailored nutrition training. PLoS One. 2014;9(5):e98308. https://doi.org/10.1371/journal.pone. 0098308.

39. Chiabi A, Lebela J, Kobela M, Mbuagbaw L, Obama MT, Ekoe T. The frequency and magnitude of growth failure in a group of HIV-infected children in Cameroon. Pan Afr Med J. 2012;11(1).

40. Fagbamigbe AF, Adebowale AS, Ajayi I. An assessment of the nutritional status of ART receiving HIV-orphaned and vulnerable children in south-West Nigeria. Heliyon. 2019;5(12):e02925. https://doi.org/10.1016/j.heliyon.2019. e02925

41. Anigilaje EA, Olutola A. Prevalence and risk factors of undernutrition among antiretroviral-therapy-naïve subjects aged under 5 years old in Makurdi, Nigeria: a retrospective study. Int J Gen Med. 2015;8:131. https://doi.org/1 $0.2147 /$ IJGM.S73881.

42. Teklemariam Z, Mitiku H, Mesfin F: Prevalence of anemia and nutritional status among HIV-positive children receiving antiretroviral therapy in Harar, eastern Ethiopa. Hiv/aids (Auckland, NZ) 2015, 7:191.

43. Mwiru RS, Spiegelman D, Duggan C, Seage GR III, Semu H, Chalamilla G, et al. Growth among HIV-infected children receiving antiretroviral therapy in Dar Es Salaam, Tanzania. J Trop Pediatr. 2014;60(3):179-88. https://doi.org/1 0.1093/tropej/fmt104.

44. Jesson J, Dahourou DL, Folquet MA, Malateste K, Yonaba C, N'Gbeche M-S, et al. Malnutrition, growth response and metabolic changes within the first
24 months after ART initiation in HIV-infected children treated before the age of 2 years in West Africa. Pediatr Infect Dis J. 2018;37(8):781-7. https:// doi.org/10.1097/INF.0000000000001932.

45. Feucht UD, Van Bruwaene L, Becker PJ, Kruger M. Growth in HIV-infected children on long-term antiretroviral therapy. Trop Med Int Health. 2016; 21(5):619-29. https://doi.org/10.1111/tmi.12685.

46. Jesson J, Ephoevi-Ga A, Desmonde S, Ake-Assi MH, D'Almeida M, Sy HS, et al. Growth in the first 5 years after antiretroviral therapy initiation among HIV-infected children in the leDEA west African pediatric cohort. Tropical Med Int Health. 2019;24(6):775-85. https:// doi.org/10.1111/tmi.13237.

47. McHenry MS, Apondi E, Ayaya SO, Yang Z, Li W, Tu W, et al. Growth of young HIV-infected and HIV-exposed children in western Kenya: a retrospective chart review. PLoS One. 2019;14(12):e0224295. https://doi. org/10.1371/journal.pone.0224295.

48. Kimani-Murage EW, Norris SA, Pettifor JM, Tollman SM, Klipstein-Grobusch K, Gómez-Olivé XF, et al. Nutritional status and HIV in rural south African children. BMC Pediatr. 2011;11(1):23. https://doi.org/10.1186/1471-2431-11-23.

49. Weigel R, Phiri S, Chiputula F, Gumulira J, Brinkhof M, Gsponer T, et al. Growth response to antiretroviral treatment in HIV-infected children: a cohort study from Lilongwe, Malawi. Tropical Med Int Health. 2010;15(8): 934-44. https://doi.org/10.1111/j.1365-3156.2010.02561.x.

50. Tekleab AM, Tadesse BT, Giref AZ, Shimelis D, Gebre M. Anthropometric improvement among HIV infected pre-school children following initiation of first line anti-retroviral therapy: implications for follow up. PLoS One. 2016; 11(12):e0167565. https://doi.org/10.1371/journal.pone.0167565.

51. Jesson J, Coulibaly A, Sylla M, N'Diaye C, Dicko F, Masson D, et al. Evaluation of a nutritional support intervention in malnourished HIV-infected children in Bamako, Mali. JAIDS. 2017;76(2):149-57. https://doi.org/10.1097/QAI. 0000000000001484.

52. Haileselassie B, Roba KT, Weldegebreal F. Undernutrition and its associated factors among pediatric age children attending antiretroviral therapy in eastern Ethiopia. East Afr J Health Biomed Sci. 2019;3(1):1-12.

53. Arinaitwe E, Gasasira A, Verret W, Homsy J, Wanzira H, Kakuru A, Sandison TG, Young S, Tappero JW, Kamya MR: The association between malnutrition and the incidence of malaria among young HIV-infected and-uninfected Ugandan children: a prospective study. Malar J 2012, 11(1):1-9, DOl: https://doi.org/10.1186/1475-2875-11-90.

54. Adem AK, Alem D, Girmatsion F. Factors affecting survival of HIV positive children taking antiretroviral therapy at Adama Referral Hospital and Medical College, Ethiopia. J AIDS Clin Res. 2014:5(3).

55. Gondar E. PREVALENCE OF MALNUTRITION AND ASSOCIATED FACTORS AMONG HIVINFECTED CHILDREN AGED 6-59 MONTHS AT GONDAR UNIVERSITY HOSPITAL. NORTHWEST ETHIOPIA: DEPARTMENT OF PEDIATRICS AND CHILDHEALTH, COLLEGE OF MEDICINE AND HEATLH; 2014.

56. Arpadi S, Lamb M, Nzeyimana IN, Vandebriel G, Anyalechi G, Wong M, Smith R, Rivadeneira ED, Kayirangwa E, Malamba SS: Better Outcomes Among HIV-Infected Rwandan Children 18-60 Months of Age After the Implementation of "Treat All". Journal of acquired immune deficiency syndromes (1999) 2019, 80(3):e74.

57. Nalwoga A, Maher D, Todd J, Karabarinde A, Biraro S, Grosskurth H. Nutritional status of children living in a community with high HIV prevalence in rural Uganda: a cross-sectional population-based survey. Tropical Med Int Health. 2010;15(4):414-22. https://doi.org/10.1111/j.1365-31 56.2010.02476.x.

58. Shiferaw H, Gebremedhin S: Undernutrition Among HIV-Positive Adolescents on Antiretroviral Therapy in Southern Ethiopia. Adolescent Health, Medicine and Therapeutics 2020, 11:101.

59. Dessalegn N, Birhanu S, Birhanu M, Kassaw A, Kindie K, Adugna A: Undernutrition and Its Associated Factors Among Human Immunodeficiency Virus Infected Children on Follow Up in Amhara Region Referral Hospitals, Ethiopia, 2020. Global Pediatric Health 2021, 8 : 2333794 X211039640.

60. Echendu ST, Ugochukwu EF, Okeke KN, Onubogu CU, Ebenebe JC, Umeadi $E N$, et al. Socio-demographic determinants of undernutrition in HIV-infected under-five children. Eur J Clin Med. 2021;2(3):22-9. https://doi.org/10.24018/ clinicmed.2021.2.3.69.

61. Tiruneh CM, Walle BG, Emiru TD, Tibebu NS, Abate MW, Nigat AB, et al. Under-nutrition and associated factors among children on ART in southern Ethiopia: a facility-based cross-sectional study. Ital J Pediatr. 2021;47(1):1-10. https://doi.org/10.1186/s13052-021-01154-w. 
62. Shet A, Mehta S, Rajagopalan N, Dinakar C, Ramesh E, Samuel N, et al. Anemia and growth failure among HIV-infected children in India: a retrospective analysis. BMC Pediatr. 2009;9(1):37. https://doi.org/10.1186/14 71-2431-9-37.

63. Abate BB, Aragie TG, Tesfaw G. Magnitude of underweight, wasting and stunting among HIV positive children in East Africa: a systematic review and meta-analysis. PLoS One. 2020;15(9):e0238403. https://doi.org/10.1371/journa I.pone.0238403.

64. Padmapriyadarsini, et al. Prevalence of Underweight, Stunting, and Wasting among Children Infected with Human Immunodeficiency Virus in South India. Int J Pediatr. 2009;2009:837627, 5 pages-5. https://doi.org/10.1155/2 009/837627.

65. Jesson J, Schomaker M, Malasteste K, Wati DK, Kariminia A, Sylla M, Kouadio K, Sawry S, Mubiana-Mbewe M, Ayaya S: Stunting and growth velocity of adolescents with perinatally acquired HIV: differential evolution for males and females. A multiregional analysis from the leDEA global paediatric collaboration. Journal of the International AIDS Society 2019, 22(11):e25412.

66. Food And Nutrition Technical Assistance (FANTA): Recommendation for the Nutrient Requirements for People Living with HIV/AIDS. Available from < http:// www.fantaproject.org. . In.; 2007.

\section{Publisher's Note}

Springer Nature remains neutral with regard to jurisdictional claims in published maps and institutional affiliations.

Ready to submit your research? Choose BMC and benefit from:

- fast, convenient online submission

- thorough peer review by experienced researchers in your field

- rapid publication on acceptance

- support for research data, including large and complex data types

- gold Open Access which fosters wider collaboration and increased citations

- maximum visibility for your research: over $100 \mathrm{M}$ website views per year

At $\mathrm{BMC}$, research is always in progress.

Learn more biomedcentral.com/submissions 